International Journal of Social Sciences and Humanities
Available online at http://sciencescholar.us/journal/index.php/ijssh
Vol. 3 No. 2, August 2019, pages: 136 144
e-ISSN: 2550-7001, p-ISSN: 2550-701X
https://doi.org/10.29332/ijssh.v3n2.300

\title{
Commodification of Usada Bali: Between Profit-oriented and Negotiation of Sasana Balian
}

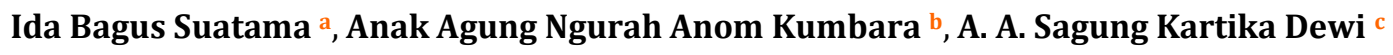

Article history: Received 27 December 2018, Accepted: 30 April 2019, Published: 26 July 2019

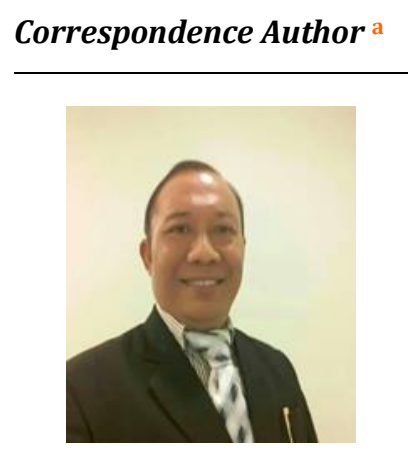

Keywords

\begin{abstract}
The purpose of this research is to understand and explain the discourse and practice of commodifying the usada Bali and negotiating the balian atmosphere in relation to economic interests. The method used is critical ethnography with qualitative analysis. This study found that the practice of commodifying usada Bali by balian was done by manipulating cultural capital, symbolic capital, and economic capital in the domains and dynamics of the habitus of usada Bali treatment to achieve economic goals. In medical practice, the balian people conduct negotiations in the gymnasium as a professional code of ethics in the midst of increasingly tighter competition in medical services. The findings of this study reflect the occurrence of mutual transformation in the practice of Balinese usada medicine due to the hegemony of modernity.
\end{abstract}

commodification;

economic;

ideology;

sasana balian;

usada Bali;

e-ISSN: 2550-7001, p-ISSN: 2550-701X ๑ Copyright 2019. The Author. SS Journals Published by Universidad Técnica de Manabí. This is an open-access article under the CC BY-SA 4.0 license (https://creativecommons.org/licenses/by-sa/4.0/) All rights reserved.

\section{Contents}

Abstract

1. Introduction.

2. Materials and Methods .

3. Results and Discussions

3.1 Usada Bali and Sasana Balian

3.2 Profit-oriented and Negotiation of the Sasana Balian 139

3.3 Form of Commodification Usada Bali

4. Conclusion 141

a Universitas Hindu Indonesia, Denpasar, Indonesia

b Universitas Udayana, Denpasar, Indonesia

c Universitas Udayana, Denpasar, Indonesia 


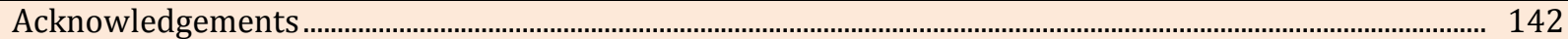

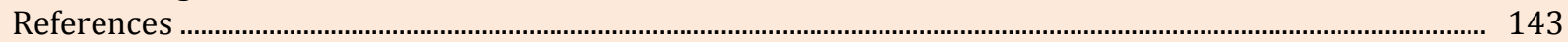

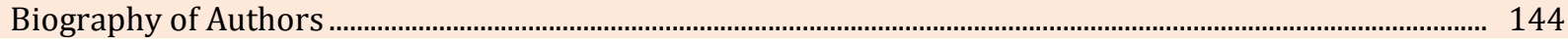

\section{Introduction}

Hindu societies in Bali generally believe that disease is caused by satanic causes ("visible causes") and scams ("invisible causes") (Nala, 1993). Foster \& Anderson (1978), states that in general traditional societies recognize two types of causes of disease, namely naturalistic causes and personality causes. This etiology is what makes the existence of traditional Balinese healers (balian) remain functional because it is believed to be able to cure diseases in a sacral and noxious manner. In this regard, Hobart (in Mbete et al., 1998), also states, "As long as the Hindu religion remains fast, people will continue to believe in being seen and unseen worlds, and there will be traditional healers." The Balinese belief in traditional Usada Bali medicine does not only occur in rural agrarian societies, but also in urban communities that have been affected by modernization, such as in Denpasar City. In its position as the capital city of the Province of Bali, Denpasar City has characterized the life of a modern society which is characterized by cities and financial economics (Simmel, in Ritzer \& Goodman, 2005; Edung et al., 2018; Rahmawati et al., 2018).

Based on the Strategic Plan of the Denpasar City Health Office 2016-2021, it was found that there were 362 traditional healers (balian) in Denpasar City with various types of expertise. On the other hand, modern health facilities, such as hospitals, health polyclinics, health centers, and practicing doctors, are available quite a lot. Nevertheless, the existence of balian in Denpasar City remains strong because they are able to adapt to the modern social environment, among others by utilizing mass media and social media to promote medical services.

This phenomenon implies the commodification of Bali's Usada by balian in Denpasar City. According to Marx (in Lash, 2004), commodification is a sociocultural process that places cultural elements as commodities. Commodities are anything that has an exchange rate, meaning everything that is sold to the market. In the process of commodification, markets emerge as new forces that shape the world and everyday life by moving traditional boundaries and bonds following the logic of the market (Abdullah, 2006). Following the market's way of thinking, Usada Bali as an element of Balinese culture that is full of the value of local wisdom has been positioned equally with other productive economic commodities.

Usada Bali as a system of knowledge or local wisdom of Bali is not really an economic element of economic value, although it can have economic impacts. Remember that each balian is bound by a set of values called the balian sasana. One of the ethical rules contained in balian sasana is the prohibition to ask for compensation to the patient unless the patient gives it sincerely in the form of sesari. So, the tradition of matari sesari (giving rewards as sincere) as a thank you for the help given balian, not as a reward for services. Therefore, the number and shape are not determined. Giving a sesari is also seen as a prayer of success for the treatment carried out, namely "floating mesari" ("good luck"). It is in this tradition of giving sesari that a person receives an economic impact from the medical services provided to patients. But along with the commodification of Balinese Usada, the meaning of sesari has shifted to a service fee, even the balian set certain rates for each patient who uses his services. This phenomenon is the focus of this study, especially to understand and explain the relations of profit-oriented and negotiation between balian sasana in the commodification of Balinese Usada, especially in Denpasar City. Thus, this study can explain the shift and transformation of traditional values as a result of modernization and globalization, particularly in the practice of Balinese usada medicine.

\section{Materials and Methods}

This study used a qualitative critical ethnographic method with a research location in Denpasar City, Bali. Data is collected through observation, in-depth interviews, and document studies. Observation is done by observing the medical practices carried out by the balian, the practice site, and the facilities and infrastructure used. Interviews were conducted with informants, which consisted of patients and patients. Meanwhile, document studies were carried out by analyzing government documents, news on mass media, pictures, and traditional Balinese literature in the form of eaves of Usada Bali and balian sasana. Data analysis was performed by critical ethnographic method Madison (2011), and descriptive-interpretative through two steps, namely 'thinking and reflecting' and 'thinking of

Suatama, I. B., Kumbara, A. A. N. A., \& Dewi, A. A. S. K. (2019). Commodification of usada bali: between profitoriented and negotiation of sasana balian. International Journal of Social Sciences and Humanities, 3(2), $136-144$. 
thought' (Geertz, 1973). This means that data collection and interpretation does not stop at one stage of meaning, but through critical reflection on empirical knowledge and practice in political relations and power and previous theoretical thoughts.

In this study, Gramsci's thinking about hegemony, Bourdieu about social practice, and Foucault's power relations and knowledge were explored in-depth to understand multivariate data in the field. Gramscian hegemony is used to understand the balian mechanism in practicing power to patients through moral and ideological leadership (Hendarto \& Putranto, 1993; Simon, 2000). The theory of social practice with the generative formula "(habitus x capital) + domain $=$ practice" (Bourdieu, 2010), is used to analyze the ability of the balian to accumulate these four aspects in the commodification of Usada Bali, especially to legitimize its existence and win public sympathy. Meanwhile, Foucault's relations and power theory (in Carrete (Ed.), 1999), was used to analyze the reproduction of medical discourse as the practice of the power of the balian in order to win the competition for medical treatment services.

\title{
3. Results and Discussions
}

\subsection{Usada Bali and Sasana Balian}

Health anthropology distinguishes the treatment system into 2 (two), namely modern medical systems and traditional medical systems with explanations as follows.

\begin{abstract}
"Within medical anthropology, a distinction is often made between biomedicine, or" western 'medical systems and ethnomedicine, or the local system of indigenous beliefs and practices surrounding health and illness "(Sikkink, 2009).
\end{abstract}

The explanation shows that modern medical systems are biomedical systems (biomedicine) developed in the Western world, while traditional medical systems are ethno medical that develop in local beliefs and practices about health and disease. Both of these medical systems standalone according to the system of knowledge or the concepts and theories underlying them (Foster \& Anderson, 1978). Usada Bali is categorized as traditional medicine typical of Balinese ethnicity. According to Nala (1993), the word usada is derived from the word ausadhi (Sanskrit), meaning plants containing medicinal properties. Meanwhile, (Sukartha, 2014; Kumbara et al., 2018; Jirnaya, 2016), defines Usada Bali as the science of traditional Balinese medicine. This medicine comes from Ayur Veda, traditional literature in the form of lontar usada in Bali, local knowledge, and supernatural beliefs.

In practice, Balinese Usada treatment is carried out by a healer called balian. Based on how to obtain expertise in the treatment of Usada Bali, the balian can be distinguished into (1) Balian ketakson, namely balian whose ability to treat is not obtained through the learning process, but the will of an ancestor or Bhattara, (2) Balian kapican, namely balian whose ability to treat comes from sorcerer objects, such as kris weapon, gemstones, and others, (3) Balian usada, namely balian whose ability to treat is obtained by the method of studying traditional Balinese medical texts, namely usada lontar, and (4) Balian of mixture, which is a combination of the first or second balian type, plus study of texts (Nala, 1993; Kumbara 2010; Wirawan, 2018; Suparna et al., 2018).

These types of balian indicate that to carry out their medical practices, a balian does not only rely on an empirical-rational treatment system, but also through religious powers that are totally irrational (Suatama, 2005). Usada treatment in Bali is empirically-rational, mainly used to treat diseases due to "visible causes", such as the use of herbs from plants, animals and other minerals. On the contrary, causes that are not looks (causa niskala), such as the punishment of God (one of the gods), the curse of the ancestors, the influence of black magic, etc., are overcome by magical-religious treatment. These two systems of medicine were actually contained in several eaves in Bali, including Usada Budha Kacapi, Usada Buduh, Usada Cukildaki, Usada Dalem, Usada Kacacar, Usada Manak, Usada Kurantabolong, Usada Pamugpug, Usada Sasah Babai, Usada Pamugpugan, Usada Ceraken Tingkeb, Usada Netra, Usada Edan, Usada Rare, Usada Ila, Usada Tiwang, Usada Pangraksa Jiwa, Usada Kuda, and Usada Taru Pramana.

In lontar usada, it is generally explained about the causes of disease based on certain characteristics (tetenger gering), ways of diagnosis, and methods of healing (Jirnaya, 2011). Given that Balinese Usada treatment is closely related to religious-magic so that moral and spiritual values bind the profession of a balian. In carrying out the profession of medicine, the balian is bound by rules or codes of ethics called Dharma Sasana Balian or commonly called sasana balian. The Balian gym that applies in the treatment of Usada Bali includes: (a) keep all the secrets of the person who is sick, may not be disseminated, or discussed with others; (b) balian life must be sacred, regardless 
of lobha (greedy), arrogant, and immoral. This is found in the speech of Bhagawan Siwa Sempurna, that a balian must not act arrogantly, must behave well according to dharma (rules of virtue), and all passions should be held in the heart; (c) a balian may not feel anxious, hesitant, and ashamed. In his heart, he must be firm, steady and have confidence in what he does. Do not falter with all obstacles, obstacles, disturbances, and temptations that come from within yourself that cause the failure of the business. Abstinence before succeeding in getting what is being experienced, what is desired, namely the healing of a sick person; (d) in carrying out his profession as a medical practitioner, a balian cannot give permission, all treatments must be carried out sincerely. A balian who is truly balian, knows the consequences of temptation will be a penance (reward) and other material; (e) the balian must know their rights and obligations, be humble not arrogant, limit themselves to what they do, respect human life, because in the body of sarira (human body) resides Sang Hyang Atma or Sang Hyang Bayu Pramana who can curse the balian breaking the rule.

Whenever you are damned, the magic and ability to treat will decrease and disappear. A balian will also receive a curse from Sang Hyang Budha Kecapi that his life will suffer (Idward, 2013). Sasana balian provides bond and boundary value to the balian in carrying out their profession. In point (d) it is clearly stipulated that $a$ balian may not make a reward (sesari) as a motivation to treat a patient. This attachment to the gymnasium will make a balian think again to collect wages for his medical services, while at the same time limiting the commodification of Balinese Usada. For this reason, the commodification of Usada Bali actually violates one of the ethics which is regulated in sasana. Therefore, when a balian is brave to break it, it can be expected that there is another value that has greater strength than the balian system. It is here that modernization has an important role in offering a new set of values that marginalizes the traditional order so that violations of the atmosphere are unavoidable.

\subsection{Profit-Oriented and Negotiation of the Sasana Balian}

Kumar (in Stzompka, 2007), states that profit-oriented is one of the characteristics of modernization, namely that all aspects of social life are dominated by economic activities, economic goals, and economic achievements. Accordingly, Abraham (1991), also states that modernization is a comprehensive process of economic growth, social mobilization, and cultural expansion. Economic growth encourages the expansion of the cultural range that presents various alternatives for each individual to achieve economic progress. Therefore, Boudrillard (in Storey, 2004), asserts that humans have reached the stages of social and economic development so that it is impossible to separate the productive economic world from the ideological and cultural world. What is striking in this trend is the growth of consumer culture in urban areas as market expansion (Abdullah, 2006). In an increasingly consumptive society, economic opportunities are increasingly open in various fields, including health. This provides an opportunity for the medical services industry as a potential economic alternative. Moreover, health is seen as a basic human need that is never interrupted from time to time, such as the statement of the following informant.

\footnotetext{
Health is like nine basic ingredients, definitely needed by the community. Every day there must be sick people, so the hospital is never quiet. For me, this is a great opportunity to be used as employment opportunities for people who have competencies in their fields. Because of that, I and my husband pioneered an herbal business because we in Bali have a lot of nutritious medicinal plants, and that can be learned from the Balinese lontar leaves inherited from the ancestors. The community seems to be interested in consuming herbs, so it's just a way to package and promote it. Informant Ariasih, 46 years old Usada Bali practitioner (herbalist) (interview, March 2019)
}

Not much different from that, other informants also disclosed, such as it is impossible for people not to be interested in money, especially today. Almost everyone measures a person's success with his economy. I am not hypocritical either. Because of this expertise that I have, this is what I use to fulfill my daily needs. Something that is important in a reasonable corridor, in my opinion, there is no harm. If it is a sesari (reward from a patient), I have never targeted it, but if there are medicines that need to be purchased, I have to say how much it costs. How else, I also need capital to buy medicinal ingredients. Yatra informant, practitioner Balian Usada, 46 years old (interview, January 2019). The two informants' expressions above confirm that Usada Bali treatment has become an economic activity in the context of the medical services industry. Both balian view traditional medical services (Usada Bali) as productive economic opportunities along with the high market demand. In the first informant, information about medicinal plants in the texts of Usada Bali was the main source for producing herbal medicines that were ready for sale. While

Suatama, I. B., Kumbara, A. A. N. A., \& Dewi, A. A. S. K. (2019). Commodification of usada bali: between profitoriented and negotiation of sasana balian. International Journal of Social Sciences and Humanities, 3(2), $136-144$. https://doi.org/10.29332/ijssh.v3n2.300 
in the case of the second informant, his treatment ability was used as a source of income by collecting a penny (reward) given by the patient.

Motivation to get a sesari negotiated with sesana through a discourse does not set a target amount (tariff) even though for certain types of drugs, it conveys the costs that must be paid by the patient. Apart from the discourse built by the balians to manipulate the way they carried out the usada practice of Bali, this fact shows the strength of economic motives. Economic ideology and negotiation between the cultural institutions for the sake of economic interests in the context of the commodification of Balinese usada medicine marked the weakening of the power of traditional power centers so that they did not have authority in the social arrangement. Reorganization of life in various aspects can be seen in three processes as characteristics of modern society. First, the materialization process of life transforms things as commodities so that there is widespread commodification. Second, social pressure due to the capitalistic work ethic encourages the emergence of the meaning of life and life as a process of seeking material added value. Third, social mobility, which is the latest phenomenon of the 21 st century, influences various forms of social, economic and political reorganization (Abdullah, 2006).

\subsection{Form of Commodification Usada Bali}

The commodification of Bali's usada cannot be separated from the still high public trust in the etiology of the kerala so that it does not fully surrender its medical treatment to conventional medical matters. In addition to these factors of trust, the reasons for patients to seek treatment for balian are also based on different motivations. Regarding these motives, Giddens (2011), argues that the underlying consciousness of human action is important to be observed, namely discursive awareness and practical awareness. Discursive awareness underlies deliberate action by the actor so that the actor is able to explain the reasons underlying his actions. Conversely, praxis awareness involves intentional or unintentional actions, but these actions are considered true even though the actor himself is unable to explain the reasons for his actions (Ritzer \& Goodman, 2005). So, discursive awareness is built through the typical of actors, while praxis awareness tends to be driven by actor motives for practical purposes.

In fact, not all patients can explain the reason for treatment at the hospital rather than the doctor, such as the statement of the following informant.

What is it! The point is I'm trying to get puffy. Anything that people suggest, I follow. To the doctor, balian, the shaman in Java has also been. The point is that the sack and nisakala all work. I did not think about whether it was true or not, the important thing was that I recovered. Sumatra patient, 54 Th., (Interview, January 2019).

From the informant, it can be seen that seeking healing is the main reason for doing treatment, both medical and nonmedical. Psychologically, this reason is reasonable for the patient because he feels that his health is threatened (Sundari, 2004). Fear of health threats creates an excessive sense of panic in the patient resulting in (a) the patient fails to think normally and adjust to the situation at hand; and (b) patients fail to understand their health problems and choose appropriate preventive measures (Ramiah, 2005). It was proven that the patient had taken all types of treatment based solely on the information obtained, even he himself did not know the correct or wrong treatment measures chosen. That is, the patient himself is unable to explain the reason for choosing treatment unless the goal of praxis is to immediately recover from his illness. Practical awareness of the motives of patients shows their failure to address the problem of their illness and find solutions according to the principles of rationality. The urge to get healing quickly moved the patient to entrust his health affairs to the balian. This praxis awareness is capitalized by Usada Bali medical practitioners in Denpasar City to fight for their economic interests. Capitalization of praxis awareness of patients through optimization of habitus, capital, and the realm marking the commodification of Usada Bali. Habitus is an individual's mental or cognitive structure to address social life (Ritzer \& Goodman, 2005). Inside and through habitus, humans perceive, understand, appreciate, and evaluate social reality. Bourdieu's domain, arena, or field (field) is a realm of strength, namely the domain that requires various potentials to exist and the struggle for positions to take place. Capital includes material (economic capital), attributes that cannot be touched, but have cultural significance, such as prestige, status, and authority (symbolic capital), as well as cultural value and consumption patterns such as property, art, and language (capital culture). These three concepts are expressed in the generative formula of social practice, namely "(Habitus x Capital) + Domain = Practice" (Bourdieu in Harker et al., (Ed.), 2009).

Habitus of the healers of Usada Bali cannot be separated from the influence of modern values that determine the value of tastes, such as rationalism, materialism, individualism, and hedonism. It is this habitus that is negotiated with the healing capital of Usada Bali, both economic, symbolic and cultural. Economic capital includes property 
owned by the balian; symbolic capital especially the status and authority of the balian who are attached to their abilities; and cultural capital in the form of linguistic abilities and various properties to influence patients. Habitus and capital are mobilized together in the realm, namely the high trust of patients towards Usada Bali and their praxis awareness. So, the trust and awareness of patient praxis is a productive domain to be capitalized according to habitus and capital in medical practice. This capitalization can be seen in the two poles of traditional consciousness and the poles of modern consciousness.

In the poles of traditional consciousness, it seems that symbolic and cultural capital is more optimized by the balian people, such as equipping themselves with accessories or properties that have magical nuances. For traditional Balinese society, the existence of accessories or property is important to build patient trust because the gift of supernatural power is seen to support healing efforts. On the contrary, at the pole of modern consciousness appears in the form of industrialization of herbal medicines which is accompanied by a discourse that these drugs can be used as complementary medical drugs without side effects. This discourse seems to succeed in grabbing patient awareness, as the following informant's statement.

If I followed the doctor's advice, I should have been operated on, but while I was advised to take medicine only. Until now, I still regularly take medicine from a doctor, but I also take a medicine that is given balian. I heard that traditional medicine had no side effects. Who knows if both of them work, I can recover quickly. Dewi 36 Th (interview January 2019)

In scientific discourse, the use of herbal medicines as a complement to chemical drugs is actually debatable. However, the patient's trust in the discourse delivered by balian made them follow that view. The discourse can only be understood by its function in the context of balancing position in front of patients in the context of power hegemony. The reproduction of discourse by involving power and knowledge such as Foucault's view (in Barker, 2005), can be seen as the most rational step for balian to capture patient awareness. Thus, there is a close relationship between the repositioning and reproduction of medical discourse in the context of mastering the awareness of patients to take the medication given. In this technological age, the form of commodification of Balinese Usada is also found in the many people who use public spaces, especially mass media and social media to do personal branding. With regard to personal branding, Montoya (2002), explains the following.

Personal branding lets you control how other people perceive you ... You're telling them what you stand for but that's how organic and innovative that perception is by themselves ... When done right, it's irresistible.

Personal branding is an increase in selling value to consumers. The use of public space as a personal branding media also seems to be the dominant trend lately. According to Habermas (in Hardiman, 2009), public space is a shared space as a reservoir for simple social interactions. For example, Jero Ni Wayan Sutiawati used the Bali Post print media to branding herself as a balian who had supernatural abilities since childhood. He also has high social life, such as doing free medication at certain moments (Bali Post, September 4, 2010). Even though other facts show that he set a registration fee, it is compensation for the patient's fees. In contrast, Jero Mangku Robinson branding himself in the name "Balian Zaman Now" utilizes youtube media. Meanwhile, Ida Bagus D. Argawana was founded by the Mahattama Giri Kusuma Foundation and provided free health consultation services on Bali TV media. In social media, such as Facebook, Instagram and Twitter, there are still many more people who popularize themselves and their medical expertise.

Personal branding is an inseparable part of the commodification of Usada Bali, especially in the contestation of the traditional health services industry. Although Usada Bali is in contact with supernatural powers that are considered sacred and sacred (fetish), but the reification law requires that the fetish be a commodity. Turner (2003), it is only in capitalism, the economic basis that causes material interests to spread within each social structure. Meaning that, Adorno (in Strinati, 1995) also states that fetish values take place when money becomes the main benchmark in the triangle of media relations, advertisers, and audiences. In short, money has replaced the value of the fetish of a commodity, including a commodified culture itself contains fetish value.

Suatama, I. B., Kumbara, A. A. N. A., \& Dewi, A. A. S. K. (2019). Commodification of usada bali: between profitoriented and negotiation of sasana balian. International Journal of Social Sciences and Humanities, 3(2), 136-144. https://doi.org/10.29332/ijssh.v3n2.300 


\section{Conclusion}

The Commodification of Usada Bali became an unavoidable fact in modernization which was encouraged by economic ideology. Material charm has encouraged the balian to frame themselves and their abilities (personal framing) to get as much public sympathy as possible. In turn, the material becomes the goal to be achieved so as to mark commodification in the broadest sense. In this case, Usada Bali as Balinese traditional knowledge that is full of value is positioned as a commodity exchanged on the market. In the process of commodification, exchange rates dominate use values so that irrational discourses are manipulated and instrumental to gain public sympathy. Moralspiritual ambivalence is unavoidable in the commodification. In this case, moral and spiritual values in the balian sasana have been negotiated with material interests through the practice of discourse. Spirituality was mobilized and instrumental in such a way as in public spaces to win the sympathy of the people who still made spirituality a reference for determining treatment options. Conversely, the spirituality inherent in a balian person also experiences ambivalence in itself, because it is difficult to separate spiritual representations and images in market mechanisms that are based more on material exchange. Thus, the commodification of Usada Bali is interrelated with profitoriented as a feature of modernity and balian negotiation as a side of the inevitable paradox. In other words, in the practice of medicine, the balian conduct negotiations as a professional code of ethics in the midst of increasingly fierce competition for medical services, and this reflects that there has been a transformation in the practice of Balinese Usada treatment due to the hegemony of modernity.

\section{Acknowledgments}

We would like to express our gratitude to Prof. Dr. A.A. Anom Kumbara, the Doctorate Program Coordinator of Cultural Study Program for his contribution in completing the author study, and Mr. Nanang Sutrisno who gave lots of contribution for this research. 
References

Abdullah, I. (2006). Dekonstruksi Komunitas: Dari Homogenitas Nilai ke Diferensiasi Praktik Sosial. Dalam Konstruksi dan Reproduksi Kebudayaan. Yogyakarta: Pustaka Pelajar.

Abraham, M. F. (1991). Modernisasi di dunia ketiga suatu teori umum pembangunan. Yogyakarta: Tiara Wacana Yogya.

Adorno, T. W. (2004). The Cambridge Companion to Adorno. Cambridge University Press.

Barker, C. (2005). Cultural studies: teori dan praktik.

Bourdieu, P. (2010). Arena produksi kultural: sebuah kajian sosiologi budaya. Yogyakarta: Kreasi Wacana.

Carrete, M., Martínez-Padilla, J., Rodríguez-Martínez, S., Rebolo-Ifrán, N., Palma, A., \& Tella, J. L. (2016). Heritability of fear of humans in urban and rural populations of a bird species. Scientific reports, 6, 31060.

Edung, T., Triguna, I. B. Y., \& Utama, I. W. B. (2018). Balian Wara position of Dayak Lawangan. International Journal of Linguistics, Literature and Culture, 4(4), 103-111. https://doi.org/10.21744/ijllc.v4n4.272

Foster, G. M., \& Anderson, B. G. (1978). Medical anthropology. John Wiley \& Sons, Inc. 605 3rd Avenue, New York, NY 10016, USA.

Geertz, C. (1973). 1973 The Interpretation of Cultures (New York: Basic Books).

Giddens, A. (2011). Posledstviya sovremennosti [The Consequences of Modernity]. Moscow: Praksis.

Hardiman, F. B. (2009). Demokrasi deliberatif: menimbang negara hukum dan ruang publik dalam teori diskursus Jurgen Habermas. Kanisius.

Harker, R., Mahar, C., \& Wilkes, C. (2009). Ranah= Praktik: Pengantar Paling Komprehensif kepada Pemikiran Pierre Bourdieu. Yogyakarta: Jalasutra.

Hendarto, H. \& Hendar, P. (1993). Mengenal Konsep Hegemoni Gramsci dalam Diskursus Kemasyarakatan dan Kemanusiaan. Jakarta: Gramedia.

Jirnaya, I. K. (2011). Usada Budha Kacapi: Teks Sastra Pengobatan Tradisional Masyarakat Bali. Disertasi. Denpasar: Program Pascasarjana Universitas Udayana.

Jirnaya, I. K. (2016). Lontar roga sanghara bhumi: ritual referention for natural balancing in Bali. International Research Journal of Management, IT and Social Sciences, 3(7), 1-8.

Kumbara, A. A. Ngurah Anom. 2010.". Sistem Pengobatan Usada Bali” dalam Canang Sari Dharmasmrti. Denpasar: Widya Dharma. HIm, 436-468.

Kumbara, A. N. A., Wiasti, M., \& Dewi, A. S. K. (2018). Transformation of siwa-sisya relationship within Hindu religiosity. International Journal of Linguistics, Literature and Culture, 4(5), 1-13. https://doi.org/10.21744/ijllc.v4n5.283

Lash, S. (2004). Sosiologi Posmodernisme (translated by Gunawan Admiranto/original title: The Sociology of Postmodernism.(London) Yogyakarta:(Rodledge) Kanisius.

Madison, D. S. (2011). Critical ethnography: Method, ethics, and performance. Sage publications.

Montoya, P., \& Vandehey, T. (2002). The personal branding phenomenon: realize greater influence, explosive income growth and rapid career advancement by applying the branding techniques of Michael, Martha \& Oprah. Peter Montoya.

Nala, I. G. N. (1993). Usada Bali. Denpasar: Upada Sastra.

Rahmawati, N. N., Kumbara, A., \& Suda, I. K. (2018). Multiculturalism towards religious life in tewang tampang village: moral education implementation based local wisdom. International Journal of Linguistics, Literature and Culture, 4(6), 63-71. https://doi.org/10.21744/ijllc.v4n6.408

Ramiah, S. (2005). Kecemasan Bagaimana Mengatasi Penyebabnya. Jakarta: Pustaka Populer Obor.

Ritzer, G., \& Goodman, D. J. (2004). Teori sosiologi modern. Jakarta: Prenada Media, 121.

Sikkink, L. (2009). Medical Anthropology in Applied Perspective. Colorado: Western State College.

Simmel, G. (1997). Simmel on culture: Selected writings (Vol. 903). Sage.

Simon, R. (2000). Gagasan-gagasan Politik Gramsci, terj. Kamdani et al. Yogyakarta: Insist.

Storey, J. (2004). Teori Budaya dan Budaya Pop, Memetakan Lanskap Konseptual Cultural Studies, terj. Elli el Fajri, Yogyakarta: Qalam.

Strinati, D. (2014). An introduction to studying popular culture . Routledge.

Suatama, I. B. Pariwisata budaya religi perspektif magis religius bali.

Sukartha, I. N. (2015). Kelisanan dalam Tradisi Mabebasan di Bali. Disertasi S3, Universitas Udayana, Denpasar. Sundari, S. (2004). Kearah Memahami Kesehatan Mental. Yogyakarta: PPB FIP UNY.

Suatama, I. B., Kumbara, A. A. N. A., \& Dewi, A. A. S. K. (2019). Commodification of usada bali: between profitoriented and negotiation of sasana balian. International Journal of Social Sciences and Humanities, 3(2), 136-144. https://doi.org/10.29332/ijssh.v3n2.300 
Suparna, I. K., Kumbara, A. N. A., \& Darmika, I. B. (2018). Homeopathy for breast cancer treatment towards Hindu women. International Journal of Health Sciences, 2(2), $25-36$. https://doi.org/10.29332/ijhs.v2n2.118

Sztompka, P. (2007). Trust: the foundation of society. Wydawnictwo Znak.

Teeuw, A., \& Bagus, I. G. N. (1998). Proses dan protes budaya. BP.

Turner, M. W. (2003). The role of mannose-binding lectin in health and disease. Molecular immunology, 40(7), 423-429. https://doi.org/10.1016/S0161-5890(03)00155-X

Ward, I. D., Zucchi, F. C., Robbins, J. C., Falkenberg, E. A., Olson, D. M., Benzies, K., \& Metz, G. A. (2013). Transgenerational programming of maternal behaviour by prenatal stress. BMC pregnancy and childbirth, 13(1), S9.

Wirawan, I. G. B. (2018). Surya Namaskara benefits for physical health. International Journal of Social Sciences and Humanities, 2(1), 43-55. https://doi.org/10.29332/ijssh.v2n1.78

\section{Biography of Authors}

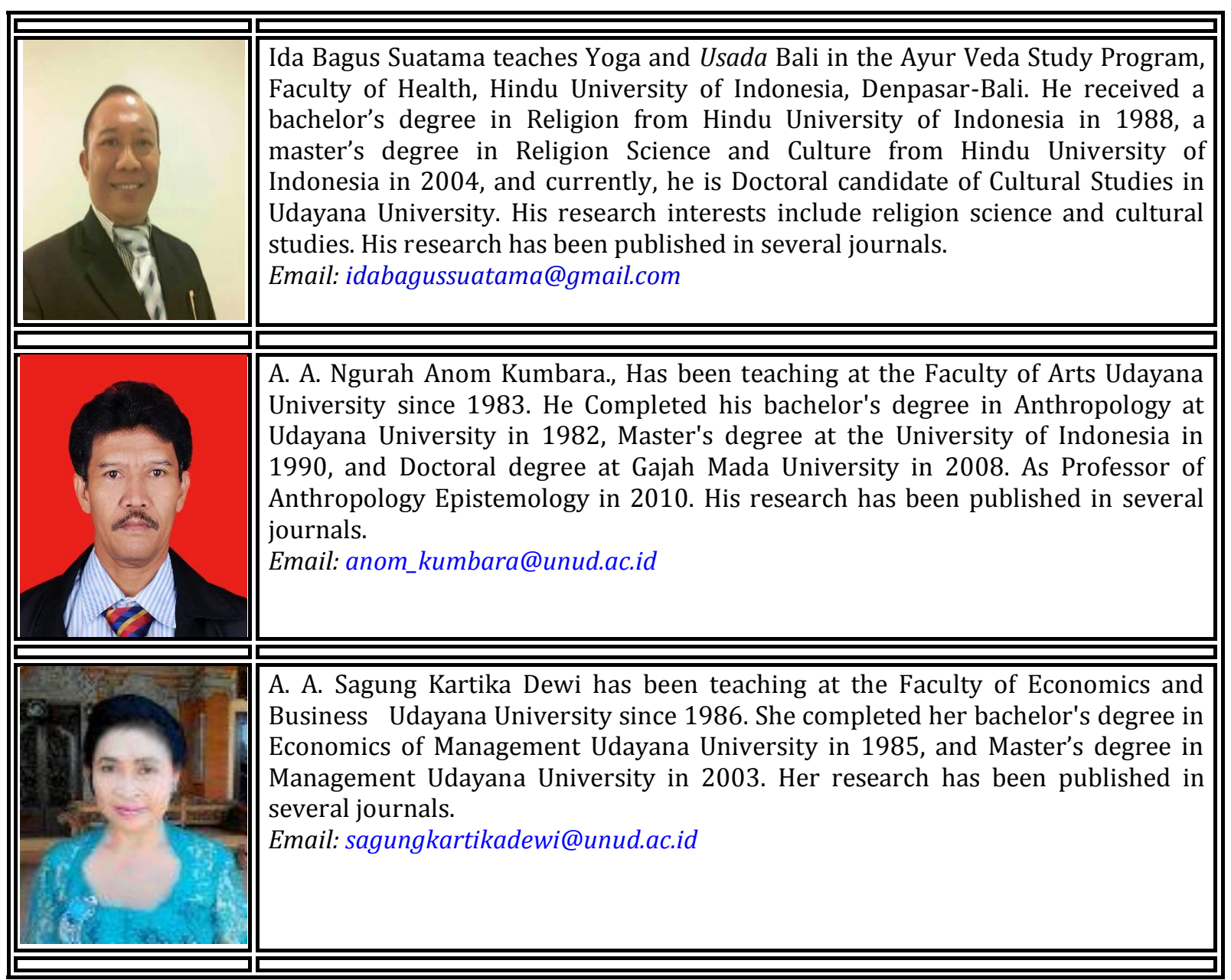

